\title{
Chemistry Teachers' Ability in Measuring Analitycal Thinking and Science Process Skills
}

\author{
Irwanto $^{1}$, Eli Rohaeti ${ }^{2}$ \\ ${ }^{1}$ Chemistry Teacher (3 Maret Senior High School Yogyakarta, INDONESIA) \\ ${ }^{2}$ Chemistry Education Lecturer (Yogyakarta State University, INDONESIA) \\ Irwan_Uny@yahoo.com
}

\begin{abstract}
The objectives of the study to investigate chemistry teachers' ability in measuring students' analitycal thinking and science process skills. This subject research is chemistry teachers' of XI IPA classes of five senior high schools in Yogyakarta. Data collecting technique used questionnaire and was analyzed in qualitative-descriptive method. The result of the qualitative analyze shows that: 1) some of the subject research teachers do not have the assessment instrument, 2) assessment laboratory activities have not using the assessment instrument, and 3) assessment instrument is not equipped with standard scoring guidelines. On the other hand, the chemistry teachers' ability in measuring analitycal thinking and science process skills is low. Therefore, chemistry teachers should be improved their ability in measuring analitycal thinking and science process skills.
\end{abstract}

Keywords: analitycal thinking, assessment instrument, science process skills

\section{INTRODUCTION}

Chemistry learning in $21^{\text {st }}$ century requires active participation of teachers to optimize the overall students' abilities on aspects of knowledge, skills, and attitudes. Knowledge related to the cognitive, psychomotor related to the skills, and attitudes related to the affective domain. Knowledge is a process of remembering, associating, assessing, and interpreting a particular phenomenon. Manual skill is the ability possessed by the students to do laboratory activities well. Attitude is a state of mind, feelings, or beliefs about a particular issue embodied in the learning activities [1]. All three of these competencies can be built through a scientific approach by using inquiry-based learning.

Inquiry-based learning is one method of learning centered on students who can improve learning outcomes of students, especially the development of higher skill. In other words, inquiry-based learning can strengthen the relationship between learning in the classroom theory with practical activities in the laboratory [2]. Inquiry-based learning is one of suitable method to apply in learning chemistry because the model facilitates the students to actively carry out an investigation in the lab activities. Inquiry-based activity involving a series of practical dimensions of knowledge students related components conceptual, procedural, and operational [3]. These three components can be obtained through practical activities that are supported by the use of science process skills.

Science process skills are intellectual skills that can be practiced, studied and developed by students through a learning process, so it makes students better prepared to face the challenges of the $21^{\text {st }}$ century learning [4]. Science process skills need to be applied to students because it indirectly will involve them in different activities and be able to direct their inquiry to apply basic science process skills and integrated [5]. These results are reinforced by the opinions Yakar [6] who argued that science process skills-based learning can also increase the positive attitude of students towards science. Thus, science process skill is able to accommodate aspects of knowledge, skills, as well as scientific attitude of the students in an integrated manner.

Competence in the science process skills should be seen as an instrument that will help students to acquire knowledge and understanding of how knowledge is acquired [7]. In the context of learning, science process skills are not directly linked to the cognitive dimension [8]. The cognitive dimension includes the students' ability to remembering, understanding, applying, analyzing, evaluating, and creating [9]. In general, the cognitive dimension in Bloom's taxonomy is divided into two levels of thinking, the low order thinking skills and high order thinking skills. Capabilities included in the low order thinking skills include 
the ability of remembering, understanding, and applying. While the capabilities included in the high-level thinking skills include the ability of analyzing, evaluating, and creating [10]. One of high-level thinking skill needed to support students' academic success in the $21^{\text {st }}$ century is the analytical thinking ability.

Analytical thinking is the thinking skills needed by students to understand the elements or holistic view. Analytical thinking is required to understand the interactions that occur between elements simultaneously connect these elements in a system in a comprehensive manner [11]. Analytical thinking is often used to solve complex problems and then make logical decisions based on the information obtained. A major component in analytical thinking consists of the ability to understand, analyze, and evaluate arguments. These components can be presented in the form of items that represent a problem. Then the problem is solved using a variety of approaches in the form of answers that need solving the problem in depth. Types of problems that have the ability to analyze are often used to measure the high order thinking skill accordance Bloom's taxonomy.

In the process of learning the need for the continuous assessment that teachers and students know the extent of achievement of the learning materials they have done. The principles in the assessment need to be done in order to provide a more optimal result in further learning. Assessment dimensions of cognitive and psychomotor will be more effective when carried out using an integrated assessment instruments. Integrated assessment is defined as a form of assessment involving all kinds of different assessment, such as written assessment (theory) and demonstration (practice) together with the aim to determine the competency of students [12]. In other words, the integrated assessment is an assessment that integrates the analytical thinking once science process skills together.

Assessment analytical thinking and science process skills can be done using a written test. One type of assessment using a form of written tests is a essay test. Essay test is a test that requires students to express the power of reason, so that the answers given will indicate the ability of complex thought. Scoring essay test can be done based on the quality of answers in every step of the completion of the given [13]. Excellence essay test form which capable of measuring the power of thought and the various aspects of the science process skills of students, so the essay test has the potential to be developed as an assessment instrument analytical thinking and science process skills. Therefore, the analytical thinking and science process skills need to be taught to students early in order to help students solve problems in meeting the challenges of the $21^{\text {st }}$ century chemistry learning.

In order to teach and assess the skills and abilities of students effectively, then the teacher must have an understanding of the operational and adequate conceptual about analytical thinking and science process skills [14]. If teachers have a low understanding of the analytical thinking and science process skills, then the possibility of science process skills teachers teach and analytical thinking will also be low. Such conditions would have a negative impact on the ability and skills of students in solving problems. Low science process skills will affect the analytical thinking of students in achieving academic success. This is because the conditions associated with the academic success of science process skills [15-21]. Students who are less trained science process skills are less likely to have good success [15]. Therefore, analytical thinking and science process skills needs to be assessed and taught to students early on so they trained in dealing with various problems in learning and the environment.

\section{RESEARCH METHOD}

This study used a qualitative approach with descriptive research. Qualitative research is research that describes and explains the experience, behaviors, interactions, and social context without actually using statistical procedures or quantification [22]. Qualitative research can use several techniques of data collection, which includes interviews, observation, and an open questionnaire [23]. The questionnaire is one of the main sources for obtaining data in the study. The questionnaire used in this study is a kind of open-ended questionnaire consisting of five questions.

The research was conducted on September 5 to 19, 2015. The subjects were five chemistry teachers of XI IPA classes of five Senior High Schools in Yogyakarta with between 6-28 years of teaching experience. Sampling was done by purposive sampling by considering school rankings (high, medium, and low) according to national test results for the senior high school (SMA/MA) grader to chemical subjects in 2015. The research subjects include MA Negeri 1 Yogyakarta, SMA Negeri 2 Yogyakarta, SMA negeri 4 Yogyakarta, SMA Negeri 6 Yogyakarta, and SMA Negeri 10 Yogyakarta. Any number of participants used in qualitative research is valid data as a source of information [24].

\section{RESULTS AND DISCUSSIONS}

In this study, the instrument used to collect data about the chemistry teachers' abilities in measuring analytical thinking and science process skills consists of 5 questions open-ended questionnaire. The 
questionnaire was given to five chemistry teacher which has a long teaching qualification more than 5 years. Reasons were selected based on the assumption that teachers are experienced in teaching, so it has a good knowledge of the chemical material, in particular the rate of reaction material. The fifth question relates to the ownership of the assessment instrument, how to conduct the assessment in practical activities, and the use of scoring guidelines in practical activities. In general, the results of the study are described as follows.

\section{A. Assessment Instrument}

Assessment instrument is a tool used to measure comprehension, mastery, and to apply the specificscientific topic or concept that has been done by students accurately [25]. The item in the questionnaire relating to the ownership of assessment instruments contained in the questions 1 and 2.

\section{1) Question 1}

Do you already have an integrated assessment instrument to measure students' analytical thinking and science process skills during practical work in a laboratory?

Based on question 1, the result that most teachers do not have an assessment instrument is to measure students' analytical thinking and science process skills during practical work in a laboratory. Ratings used to be limited on the skill and mastery of the material at the time of preparation of the practicum. In addition, the assessment instruments used do not measure the abilities and skills of students in detail or only in outline. The impact when the measurement capabilities and analytical thinking are not using science process skills assessment instrument is the result obtained is not accurate. In addition, the assessment has been carried out allowing the element of subjectivity assessors to students. One example of the results of the questionnaires by the teacher in the question 1 is presented in Fig. 1.

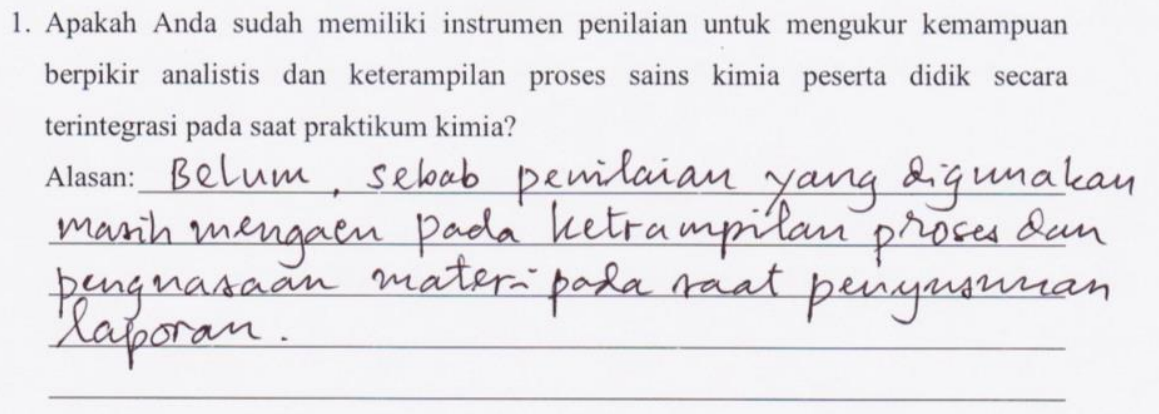

Figure 1. Teachers' Response to the Question 1

\section{2) Question 2}

\section{Are the chemistry laboratory activities that you do already use integrated assessment instrument?}

Integrated assessment is a form of assessment involving all kinds of different assessment, such as assessment of the analytical thinking and science process skills together with the aim to determine the competency of students. Based on question 2, showed that the vast majority of teachers do not use the integrated assessment instrument during chemistry laboratory activities. It is seen from the activities of teachers who only use direct observation in assessing the practical activity regardless of the indicators contained in process skills. In addition, the measurement of the analytical thinking is not optimal, and the measurement is performed separately from the practicum. One example of the results of the questionnaires by the teacher in the question 2 is presented in Fig. 2 .

2. Apakah kegiatan praktikum kimia yang Anda lakukan sudah menggunakan instrumen penilaian terintegrasi?

Alasan: Belmm

Figure 2. Teachers' Response to the Question 2

Cognitive dimension measurement performed by the teacher using a presentation about the still dominant limited remembering, understanding, and applying. It will actually make the ability of students is only used to resolve low-level cognitive problems. In fact, the analytical thinking is a high-level cognitive that can be achieved after the students master the low-level cognitive as to remembering, understanding, 
and applying. The problems arise because teachers are yet to optimize the analytical thinking and science process skills in the learning process. In addition, science process skills are rarely taught in laboratory activities because teachers assume that students can acquire these skills through practical experience in the laboratory by itself [26]. Thus, students will not have a clear concept in carrying out laboratory work skills.

\section{B. Practical Activity Assessment}

Assessment is a way of practical activities undertaken by teachers to obtain relevant information in practical activities. The results obtained in the assessment of practical activities used to determine learning outcomes, the specific individual circumstances, and improve the learning process have been done. The success of practical activities will be evaluated based on the findings or obstacles which were acquired during previous practical activities. In general, the items in the questionnaire relating to how to vote in the lab activities are in the question number 3 and 4.

\section{1) Question 3}

Does each measurement chemistry laboratory activity that you do already use integrated assessment instrument that is different between the material with each other?

Based on question 3, the result that most of the teachers do not use the integrated assessment instrument that is different between the material with each other at the time of measurement chemistry laboratory activities. In general, teachers assess practical activities based on reports from the lab that has been done by students. In addition, the practicum is only just taken from the final stage of practical activities. Thus, the assessment of practical activities between the subject matter of which one with the other is not done using the integrated assessment instruments. One example of the results of the questionnaires by the teacher in question 3 is presented in Fig. 3.

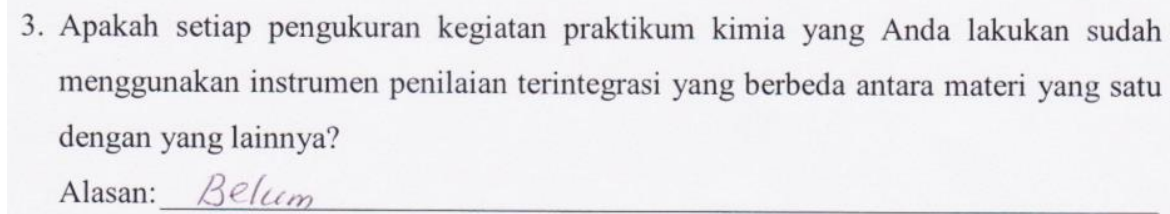
Alasan: Belum

Figure 3. Teachers' Response to the Question 3

2) Question 4

How is the way you assess cognitive and psychomotor students integrated during chemistry laboratory activities?

Based on question 4, the result that often teachers assess the cognitive and psychomotor is separately. Assessment of cognitive ability is based on the results of the lab report made by students, whereas psychomotor assessed by observation during the practical work in a laboratory. In practice, teachers only judge about discipline and cooperation of students when carrying out practical work. This leads to an assessment of the learning outcomes of students performed less effective and efficient, both in the planning, implementing, and reporting. Moreover, teachers will have more work to the assessment and administration of students' learning outcomes. One example of the results of the questionnaires by the teacher in the question 4 is presented in Fig. 4.

4. Bagaiamana cara Anda menilai kemampuan kognitif dan psikomotorik peserta didik secara terintegrasi pada saat praktikum kimia?

Alasan: prnilaian kognitif clan psikomotorik siring
terpisah. Penilaian psikomotorik $\approx$ saat
milakukan praktikum, \& penilaian kognitif
pada laporan praktikum \& ulangan harian

Figure 4. Teachers' Response to the Question 4 


\section{Scoring Guidelines}

The scoring guidelines is a guidelines in determining the score of the work of students in an objective and accountable. Scoring guidelines is important to be prepared as well as possible by teachers using clear measures in order to provide an authentic score of answers to students [27]. The item in the questionnaire related to the use of scoring in the practicum guidelines contained in question 5.

\section{1) Question 5}

Do you have scoring guidelines for integrated assessment instrument between the cognitive and psychomotor?

Based on question 5, the result that most teachers do not all have the scoring guidelines for integrated assessment instrument between cognitive and psychomotor aspects. Teachers find it difficult to design and develop guidelines for scoring the assessment tool is integrated between cognitive and psychomotor aspects. The difficulties appear due to lack of teacher knowledge about the correct preparation of scoring guidelines. In this case, this section serves as a guide for scoring results and increasing objectivity in scoring. In addition, the guidelines need to be made scoring with a clear indication that the inspection of students' work can be done with the same standard. If teachers do not have the scoring guidelines on cognitive and psychomotor aspects in an integrated manner, the assessment has not been conducted objectively. This is contrary to the Regulation of the Minister of Education and Culture No. 66 of 2013 about standard assessment in education which states that the principles of such assessment must be integrated, economical, and objective [28]. One example of the results of the questionnaires by the teacher in the question 5 is presented in Fig. 5.

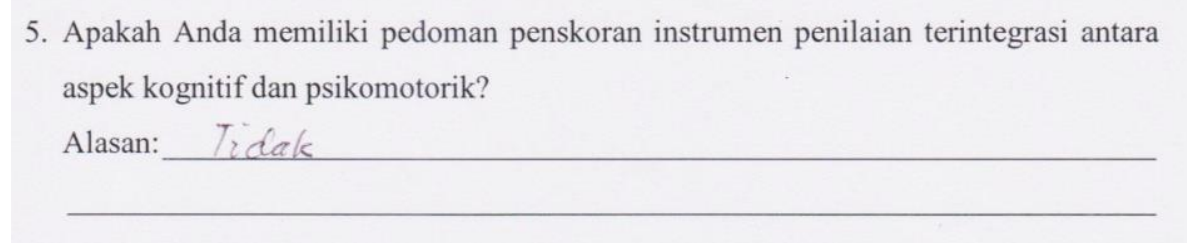

Figure 5. Teachers' Response to the Question 5

Practical activity requires an assessment instrument to be able to measure the students across the ability or competence should be measured precisely. Assessment instruments need to be designed according to the indicators of learning materials that are the standard of competence and basic competence in the applicable curriculum. However, the fact the teacher has not had an integrated assessment instrument to measure the analytical thinking and science process skills during chemistry laboratory activities. In addition, assessment also needs scoring guidelines in order to maintain consistency in the scoring gives a score for each job students. Scoring guidelines need to be prepared to use measures which systematically appropriate measures in order to facilitate the process of workmanship matter of scoring learning outcomes and avoid bias. Based on the research that has been conducted shows that teachers are also not entirely have the scoring guidelines for integrated assessment instrument between cognitive and psychomotor aspects.

Although teachers are the subject of the research has a relatively long teaching experience, but that experience does not necessarily indicate that their understanding in measuring the analytical thinking and science process skills considered good. Teachers realize that the old teaching is not necessarily able to improve control of their competence in carrying out a series of learning activities [29]. In practice, teachers focus on teaching to complete the syllabus content and deliver information in order to prepare students for public examinations [30]. This causes less teacher attention to the aspects that should be assessed in practical activities.

The level of understanding and mastery of teachers' science process skills are also associated with the level of understanding and mastery of students' science process skills [3]. Teachers who lack the conceptual knowledge of the science process skills will use the strategy of inquiry learning, so they will not emphasize these skills in the classroom [31]. Although they carry out practical activities, however, teachers have no knowledge of the underlying conceptual skills [32]. Thus, analytical thinking and science process skills owned by students will tend to be low. Low analytical thinking and science process skills will result in the inability of students in solving problems that require a high level of analytical thinking skills. Further impact that would adversely affect the students are led to the unpreparedness of students for the challenges of the $21^{\text {st }}$ century chemistry learning increasingly complex. 


\section{CONCLUSIONS AND SUGGESTIONS}

The result of the qualitative-descriptive analyze shows that: 1) some of the subject research teachers do not have the assessment instrument, 2) assessment laboratory activities have not using the assessment instrument, and 3) assessment instrument is not equipped with standard scoring guidelines. On the other hand, the chemistry teachers' ability in measuring analitycal thinking and science process skills is low. Therefore, chemistry teachers should be improved their ability in measuring analitycal thinking and science process skills through composing standardized test.

\section{ACKNOWLEDGMENT}

The authors would like to express profound thanks and appreciation to the DP2M DIKTI (Directorate of Higher Education), Ministry of Research, Technology and Higher Education Republic of Indonesia through "Tim Pascasarjana” Research Grant 2016 for the financial support.

\section{REFERENCES}

[1] A.R. Gotsch, C.W. Keck, and H.C. Spencer, (2012). Knowledge, skills, and attitudes (KSAs) for the public health preparedness and response core competency model. Retrieved from http://www.midamericacphp.com/wpcontent/uploads/2009/12/ KSA.pdf.

[2] R. Spronken-Smith, and R. Walker, "Can inquiry-based learning strengthen the links between teaching and disciplinary research?", Studies in Higher Education, 35(6), pp.723-740, 2010.

[3] E.H.M. Shahali, L. Halim, D.F. Treagust, W. Won, and A.L. Chandrasegaran, "Primary school teachers' understanding of science process skills in relation to their teaching qualifications and teaching experience", Research in Science Education, pp.1-25, 2015.

[4] K. Osman, and R. Vebrianto, "Fostering science process skills and improving achievement through the use of multiple media”, Journal of Baltic Science Education, 12(2), pp.191-204, 2013.

[5] J.P. Leonor, "Exploration of conceptual understanding and science process skills: a basis for differentiated science inquiry curriculum model", Journal of Information and Education Technology, 5(4), pp.255-259, 2015.

[6] Z. Yakar, "Effect of teacher education program on science process skills of pre-service science teachers", Educational Research and Reviews, 9(1), pp.17-23, 2014.

[7] K. Bati, G. Erturk, and F. Kaptan, "The awareness level of pre-school education teachers regarding science process skill”, Innovation and Creativity in Education, 2(2), pp.1993-1999, 2010.

[8] S.M. Mutisya, J.K. Too, and S. Rotich, "Performance in science process skills: the influence of subject specialization", Asian Journal of Social Sciences \& Humanities, 3(1), pp.179-188, 2014.

[9] D.R. Krathwohl, “A revision of bloom's taxonomy: an overview”, Theory into Practice, 41(4), pp.212-218, 2002.

[10] L. McNeil, "Beyond the products of higher-order questioning: how do teacher and english-language learner perceptions influence practice?", TESOL Journal, 2, pp.74-90, 2010.

[11] F.M. Wuketits, "Synthetic and analytical thinking", Fresenius Z. Anal. Chem., 326, pp.320-323, 1987.

[12] SAQA. (2014). National policy and criteria for designing and implementing assessment for NQF qualifications and partqualifications and professional designations in South Africa. Retrieved from http:// www.gpwonline.co.za/Gazettes/Gazettes/ 38246_28-11_SAQA.pdf.

[13] R.L. Ebel, and D.A. Frisbie, Essential of Educational Measurement. New Delhi: Prentice-Hall, Inc, 1991.

[14] J. Settlage, and S.A. Southerland, Teaching Science to Every Child: Using Culture as a Starting Point. New York: Taylor \& Francis, 2007.

[15] H. Aktamis, and Ö. Ergin, "The effect of scientific process skills education on students' scientific creativity, science attitudes and academic achievements", Asia-Pacific Forum on Science Learning and Teaching, 9(1), pp.1-21, 2008.

[16] B. Feyzioglu, "An investigation of relationship between science process skills with efficient laboratory use and science achievement in chemistry education", Journal of Turkish Science Education, 6(3), pp.114-132, 2009.

[17] E.I. Aka, E. Güven, and M. Aydoğdu, "Effect of problem solving method on science process skills and academic achievement". Journal of Turkish Science Education, 7(4), pp.13-25, 2010.

[18] I. Delen, and T. Kesercioğlu, "How middle school students' science process skills affected by Turkey's national curriculum change?", Journal of Turkish Science Education, 9(4), pp.3-9, 2012.

[19] S. Supasorn, and S. Waengchin, "Development of grade 8 students' learning achievement on chemical reaction by using scientific investigation learning activities", Procedia Social and Behavioural Sciences, 116, pp.744-749, 2014.

[20] H.E.O. Abungu, M.I.O. Okere, and S.W. Wachanga, "Effect of science process skills teaching strategy on boys and girls' achievement in chemistry in Nyando District, Kenya", Journal of Education and Practice, 15(15), pp.42-48, 2014.

[21] K. Chaurasia, "Relationship between science processes and concept-attainment in science", Global Journal for Research Analysis, 4(5), pp.316-317, 2015.

[22] E. Fossey, C. Harvey, F. McDermott, and L. Davidson, "Understanding and evaluating qualitative research". Australian and New Zealand Journal of Psychiatry, 36, pp.717-732, 2002.

[23] I.J. Ezema, C.S. Zeah, and B.N. Ishiwu, "Social networking services: a new platform for participation in government programmes and policies among Nigerian youths", LIBRES, 25(1), pp.33-49, 2015.

[24] M.A. Oun, and C. Bach, "Qualitative research method summary", Journal of Multidisciplinary Engineering Science and Technology, 1(5), pp.252-258, 2014.

[25] W.K. Adams, and C.E. Wieman, "Development and validation of instruments to measure learning of expert-like thinking", International Journal of Science Education, pp.1-24, 2010. 
PROCEEDING OF $3^{\text {RD }}$ INTERNATIONAL CONFERENCE ON RESEARCH,

[26] M.T. Tan, (2000). Investigating science procedural skills among PKPG teachers after 14 weeks courses in Batu Lintang Teacher Training Institution. Retrieved from http://www.ipbl.edu.my/BM/penyelidikan/2001/2001_tan.pdf.

[27] Sumaryanta, "Pedoman penskoran", Indonesian Digital Journal of Mathematics and Education, 2(3), pp.181-190, 2015.

[28] Mendikbud. (2013). Peraturan Menteri Pendidikan dan Kebudayaan Republik Indonesia Nomor 66 Tahun 2013 tentang Standar Penilaian Pendidikan.

[29] J. Hattie, Visible Learning: a Synthesis of Over 800 Meta-analyses Relating to Achievement. London: Routledge, 2009.

[30] A.A.R. Rose, Inculcating \& encouraging science process skills among form two students in a malaysian smart school. Unpublished PhD thesis at Universiti Kebangsaan Malaysia, Malaysia, 2004.

[31] R. D. Anderson, "Reforming science teaching: what research says about inquiry", Journal of Science Teacher Education, 13(1), pp.1-12, 2002.

[32] H.U. Emereole, “Learners' and teachers' conceptual knowledge of science process: the case of Botswana", International Journal of Science 